\title{
Down Deep in the Dark: A Semiotic Approach to Edgar Allan Poe's the Black Cat
}

\author{
Abdul Karim Lazim* \\ Department of English, College of Basic Education, University of Misan, Iraq \\ Corresponding Author: Abdul Karim Lazim, E-mail: abdulkareem.lazim@yahoo.com
}

\section{ARTICLE INFO}

Article history

Received: December 07, 2017

Accepted: January 14, 2018

Published: February 28, 2018

Volume: 9 Issue: 1

Advance access: January 2018

Conflicts of interest: None

Funding: None

Key words:

The Semiotic Triangle,

Syntagmaticity,

Paradigmaticity,

Signification,

The Gothic Novel,

Culture of Horror,

Narratology

\begin{abstract}
Semiotics is the investigation of the nature, type and function of signs in all walks of life. It is the science of interpreting signs and showing how meaning is generated by and through a shared cultural code. Being a verbal corpus of imaginatively works of art, literature with all its genres, i.e. poetry, drama, fiction, the short story, etc. lends itself to semiotics scrutiny. Verbal works of artifact as such can be analyzed in terms of semiotic theory. This paper purports to explore Edgar Allan Poe' The Black Cat as a structure of interconnected signs which are organically rooted into the code of horror. If culture, in one sense, is the complex network of beliefs, behaviors and patterns of thinking, these psychopathic cognitive patterns are wittingly structured in the semiotic system of Poe's narrative work of art. The study proceeds with the hypothesis that Poe's The Black Cat is a semiotic metaphor or a representation of the actual world of insanity which is resulted from obsession in things. The short story is analyzed in terms of the newly semiotic approach, namely The Semiotic triangle. This tripartite model is a three-dimensional model whose axes are: syntagmaticity, paradigmaticity and signification. The dimensions are supposed to be the foundations of the construction of Poe's literary text. One result of the study has shown that fear is not an organic human nature in The Black Cat, but a newly born behavior which has led to a serial of crimes committed by the unnamed author. This abnormal behaviorism is encoded in the semiotic veins of Poe's newly literary genre, i.e. the narratology of horror. The scope of the study is limited to Poe's The Black Cat as a par excellent narrative work of that creative genre. The paper is rounded up with concluding remarks elicited from the semiotic analysis.
\end{abstract}

\section{INTRODUCTION}

Down Deep in the Dark, being a title is likely to suggest that in the Gothic narrative genre the reader may tread the cognitive labyrinth to reach the core of darkness. This is true to Edgar Allan Poe's The Black Cat when it is introspected from a semiotic stance. This paper purports to explore Edgar Allan Poe' The Black Cat as a structure of interconnected signs which are organically rooted into the code of horror. If culture, in one sense, is the complex network of beliefs, behaviors and patterns of thinking, these psychopathic cognitive patterns are wittingly structured in the semiotic system of Poe's narrative work of art. The study proceeds with the hypothesis that Poe's The Black Cat is a semiotic metaphor or a representation of the actual world of insanity which is resulted from obsession in things. The short story is analyzed in terms of the newly semiotic approach, namely The Semiotic triangle. This tripartite model is a three-dimensional model whose axes are: syntagmaticity, paradigmaticity and signification. The dimensions are supposed to be the foundations of the construction of Poe's literary text.

The paper purports to investigate Poe's short story as a structural semiotic world of symbols which operate reciprocally to communicate a message. Semiotics, in this respect, is the science of interpreting signs and showing how meaning is generated by and through a shared cultural code. Semiotics, hence, is a meaning - making study. But if semiotics is the epistemic descriptive sphere which views imaginatively literary works of arts as semiotic texts, more precisely as complex networks of interrelated signs, then the short story is the kind of text that lends itself to semiotics scrutiny. The researchable questions to be raised concerning the problem of the study are: What is really the semiotics of narration? Is there any semiotic structure in the Gothic narrative? How could Poe's The Black Cat be linked to the code of horror?

Modern semiotic theory views narrative as a semiotic representation of a combinatory series of imaginative events; this narrative linearity is basically based on spatial- temporal and causal manner. So, narration is not the prerogative of imaginatively works of arts, namely, long novels. As Roland Barthes (1975:237-272) has put it, "there are countless forms of narrative in the world." The French post- structuralist goes on to say that

narrative is present in myth, legend, fables, tales, short stories, epics, history, tragedy, drama [suspense drama], comedy, pantomime, paintings (in Santa Ursula by Carpaccio, for instance), stained-glass windows, movies, 
local news, conversations. Moreover, in this infinite variety of forms, it is present at all times, in all places, in all societies; indeed narrative starts with the very history of mankind, there is not, there has never been anywhere, any people without narrative; all classes, all human groups, have their stories, and very often those stories are enjoyed by men of different and even opposite cultural backgrounds: narrative remains largely unconcerned with good or bad literature. Like life itself, it is there, international, transactional, transcultural.

But if this elucidation bridges the gap between semiotics and narrative, narrative itself should not be understated as merely a sequence of episodes following each other in an inevitable way. Rather, it construes a story and a discourse. In his Story and Discourse (1978:19) delineates on the structuralist theory by stating that" each narrative has two parts: story (historie), the ontent or chain of events (actions, happenings), plus what may be called the existents (characters, items of setting); and a discourse (discourse), that is, the expression, the means by which the content is communicated." He concedes to say that the story is the what in a narrative that is depicted, discourse the how. Apparently, Chatman makes distinction between meaning and the form of meaning or the language in which the meaning is constructed, i.e. the style. In addition, an elucidation as such brings the structuralism closer to semiotics, albeit they are overlapping terms in certain semiotic studies.

Poe's The Black Cat (1843) is viewed as one of the greatest symbolic short stories in American Literature. Being set into the setting of horror, guilt, death and darkness may bring the whole story to the brink of the Gothic Novel which is wittingly invented in the final decades of the eighteenth century and the onset of the nineteenth century. The supernatural atmosphere of mystery and suspense has pervaded not only the narrative genre, but all the veins of literature. In addition to the supernatural happenings in the literary work, more specifically the narrative work, which is sometimes inexplicable madness, becomes the most characteristics of such fiction. The best image of the supernatural elements and madness is Charlotte Bronte's Jane Eyre where strange echoes are heard in the mysterious mansion, and where the mad wife of Mr. Rochester is locked there for mysterious motifs. The theme of madness is used, not only to arouse suspense and create fear, but also to explore the dark hidden areas of human nature. Not only that, the sequential episodes of the Gothic novels and short stories almost take place in gloomy, decaying and grim spheres as there were a sort of correspondence between outside nature and the internal nature of the character(s). All these Gothic hellish characteristics can be detected in Poe's The Black Cat, as the semiotic study will show.

To answer the researchable inquires, the study aims at the exploration of Poe's The Black cat as a semiotic structure of interconnected signs in terms of semiotic theory. The study proceeds with the hypothesis that Poe's The Black Cat is a semiotic metaphor or a representation of the actual world of insanity which is resulted from obsession in things. The short story is analyzed in terms of the newly semiotic ap- proach, namely The Semiotic triangle. This tripartite model is a three-dimensional model whose axes are: syntagmaticity, paradigmaticity and signification. The dimensions are supposed to be the foundations of the construction of Poe's literary text. As semantic organization, the study construes two main parts: Part I deals partially with the semiotic sphere of narration, then, with the semiotic model of analysis, while Part II is applicable, in the sense, it applies the semiotic triangle model to Poe's The black Cat. The validity of the model lies in the assumption that it seminally links the story to its cultural code. The scope of the study is limited to Poe's short story.

\section{PART I: SEMIOTICS AND NARRATION}

If semiotics is the theory of signification whose main concern is to unravel meaning products, and if structuralism is the discipline that investigates the underlying patterns of signification, narration, then, is that account of sequential meaningful events. These narrative meaningful connected events form a meaningful unit, i.e. a text. Therefore, the reciprocally interlinked concepts of signification and meaning are omnipresent in any literary text, but what about the semiotics of narration?

\section{Semiotics of Narration}

Semiotics, as has already been mentioned, is the rubric that fundamentally deals with meaning-making and meaning products, so this science of produced meaning unravels " the meanings built into all kinds of human products, from words, symbols narratives, symphonies, paintings and comic books, to scientific theories and mathematical threesome " (Danesi, 2007:7). In investigating the semiotics of narration, the main point is not to uncover the thematic structure of the literary work of art, say a short story, but also to unravel the way through which meaning is constructed by the structures of interconnected signs. So, it is not altogether wrong to say that a narrative is a tale told by a chain of combinatory signs. These signs are necessarily related to a given cultural code. Being a meaning unit, the narrative construes a complex network of signs which operate reciprocally to build up the mental image of the world. At this point of exploration, the notions of sign, code, and structure and need more insight.

Sign, in a broadest sense, is a unit of meaning that represents something other than itself. The sign sea, for instance, stands for that wide area of salty water. This conceptual or denotative sense of the sea might be extended into metaphorical or connotative sense when it is used in phrases like sea of darkness or, let us borrow Arnold's poetic phrase in Dover Beach, sea of faith. So, while denotation is the "primary, in tensional meaning of a sign (Danesi, 2004:335), connotation is the "extended or secondary meaning of a sign" (ibid, 334). Here comes metaphor, not a s a literary device, but a sign vehicle that carries a connotative meaning, as we shall see in due course. Though sign is the core of semiotic theories, these conceptual frameworks view the term differently.

In his linguistic paradigm, more specifically in his The Course in General Linguistics, Saussure (1857-1913) has 
introduces a set of dichotomies, of which is the signifier/ signified dichotomy. Being a complex system of sign, each linguistic sign represents or stands for some entity in the physical world (sea) or to a mental image (Poseidon). The verbal sign consists of two aspects- the audible (sound) and the visible (seen). Put it simply, the signifier is the sensible part of the verbal sign (the part accessible to the senses); the part you see or hear, whereas the signified is what these visible/audible aspects mean to you; it is always something of an interpretation that is added to the signifier. Inevitably, a certain amount of signification occurs (see Phillips, 2016). But if Saussure, the Swiss linguist, has related the sign to the verbal system, i.e. language, Pierce (1839-1914), the American philosopher has linked it to cognition by and through his triadic model. In his words (cited in Stanford Encyclopedia of Philosophy,2017): "I define a sign as anything which is so determined by something else, called its Object, and so determines an effect upon a person, which effect I call its interpretant, that the later is thereby mediately determined by the former." Pierce's utterance clearly shows that his model is of three dimensions: the sign, the object and the interpretant. To bring Pierce's model to that of Saussure, Stanford Encyclopedia of Philosophy elaborates on the former tripartite mode by saying that we can think of the sign as the signifier, for example, a written word, an utterance, smoke as a sign for fire etc. The object, on the other hand, is best thought of as whatever is signified, for example, the object to which the written or uttered word attaches, or the fire signified by the smoke. The interpretant, the most innovative and distinctive feature of Pierce's account, is best thought of as the understanding that we have of the sign/object relation (ibid). The importance of the interpretant for Pierce is that signification is not a simple dyadic relationship between sign and object: a sign sigifies only in being interpreted. This makes the interpretant central to the content of the sign, in that, the meaning of a sign is manifest in the interpretation that it generates in sign users (ibid). Though the two models have shared the same concern, i.e. the sign, Saussure's dyadic model and Pierce's triadic one are distinct in their epistemic outline.

The sign, as has already been denoted, is a meaning unit, meaning it is a meaning transmitter. To be so, the sign should have a structure. So, what is really the structure? There is a general consensus amongst modern linguistic views that the structure is hierarchical organization of a relational nature. From a structuralist view, the structure is " a set of syntagmatic relations holding among the elements of a sentence or some distinguishable subpart of a sentence- in other words, the particular way those elements are put together to make up that sentence or subpart (Trask, 1993:263).

From a semiotic stance, the term structure can be applied to "any repeatable, systematic, and patterned, or predictable aspect of signs, codes, and texts" (Danesi, 2007:143). A language, for instance, is a structure, in the sense that it is a network of interrelated signs, the meaning of the parts being specifiable only with reference to the whole. In this sense, the two terms, structure and system are often synonymous (Crystal, 1997: 439).

We have said that words function when they operate reciprocally in a given context. Still, the words in human languages are not used haphazardly. In communication, comprehending meaning should occur between two participants at least, i.e. an addresser or speaker and an addressee or hearer in the communicative process. To be communicative, there should be a degree of agreement between the participants about the encoded meanings of signs. This set of rules that designates communication has been referred to as code. Semiotically speaking, codes are "systems of signs that people can select and combine in specific ways (according to the nature of the code) to construct messages, carry put actions, enact rituals, and so on, in meaningful ways" (Danesi, 2007: 64). In other phraseology, the code is " the system in which signs are organized and which determines how they relates to each other and can thus be used for representation and communication" (ibid: 136). Codes, off course, are of different types, of which is the narrative code. A narrative, in the semiotic theory, is a representation of human episodes; the components of these events are the chosen signs in combinatory chains of structures. This elucidation may pave the path to comprehend the semiotics of narrative. Hence, any narrative is a form of meaning since it has a definite structure and is recreates in a narrative code. Being a text with a specific fabric or texture, the narrative can lend itself to semiotic interpretation in terms of a specific model.

\section{The Semiotic Triangle (ST) as a Model}

A narrative is an account of imaginatively sequential strings of signs and symbols. Being a larger sign, this meaning product can be analyzed differently within different semiotic frameworks. Then, the so - called The Semiotic Triangle (henceforth $S T$ ) is our proposed model for the semiotic interpretation of Poe's The Black Cat. The model is semiotic since it is grounded in the theory of signs and symbols, and triangle since it has recourse to the structural parameters of syntagmaticity, paradigmaticity and signification. These structural terms need more exploration.

The structure, as indicated, is a set of syntagmatic relations holding among the elements of a sentence. In a linguistic structure every linguistic item enters into, basically a linear relation with other items in the span. The relation itself is fundamentally based on combination; it is a sequential relation. Syntagmaticity is a structural parameter which exists in language, spoken or written. Here, the linguistic structure is hierarchically arranged as sequences of constituents. These constituents operate reciprocally; they are in syntagmatic relation. The syntagmatic relation, in Trask's words (1993:273), is "any relation holding between two elements which are simultaneously present in a single structure, such as that between a verb and its object." A structure like, The white lord whipped the black slave severely, is a well-formed string syntactically and semantically. There is a concord between the actor, the white lord, which is a nominal group, and whipped which is a verbal group. The actant is that of a power abuse which implicitly refers to the colonial period tradition. The syntagmatic relation is formed by the mutual operative constituents in the opposing cultural code.

If the syntagmatic relation is based on sequence, com- 
bination and horizon, the paradigmatic relation is grounded in opposition, selection and verticality. Paradigmaticity, according to Sebeok (2001: 155), is "a differentiation property of forms." It refers to "a structural relation between signs that keeps them distinct and therefore recognizable "(Danesi and Sebeok, 2000:141).

The paradigmatic relation, as mentioned, is based on the concept of binary opposition. Germinated in the Saussurean structural linguistics, binraism or the binary system is " a pair of related terms or concepts that are opposite in meaning." (Fogarty, 2005). Binarism is a device normally used to by which the units of language have value or meaning; each unit is defined in reciprocal determination with one another term, as in binary code. Applied to our illustration, the white lord stands in binary opposition with the black slave which falls within the scope of slavery code which is culturally crucial part of the colonial system. The other characteristic of paradigmaticity is that it is based on the notion of substitution. The normal pro-form of the noun in the nominal group is the pronoun. In our citation, the nominal group, the white lord, as an actor cab substituted by he, whereas the black salve, being a patient, is substituted by him. The value or the meaning of these constituents is highlighted by the device of binarism.

The syntagmatic/paradigmatic poles are of cardinal importance in meaning production. They are crucial aspects of the semiotic system and capable of producing meaning potential. Saussure, (cited in Chandler, 2007:83) speculates that "meaning arising from the differences between signifiers; these differences are of two kinds: syntagmatic (concerning positioning) and paradigmatic (concerning substitution). Chand let (ibid) thinks that such a distinction if of significance to structural semiotic analysis in which these two structural axes (horizontal as syntagmatic and vertical as paradigmatic) are seen as applicable to all sign system. This this, off course, not the whole story. The third angel that is interlinked to forms of meaning is signification.

All semiotic structures, whether denotative (referential, literal) or connotative (associative, metaphorical) include the process of signification. Semiotics, as discipline, is theory of signification. Signification is a "relation that holds between a form and its referent" (Danesi and Sebeok, 2000: 223). Put it this way, signification is "the process of generating meaning through the use of signs" (Danesi, 2007:143), In the literature of semiotics, these two concepts, meaning and signification, are used synonymously. This is so because the ultimate goal of semiotics is to detect the form of meaning in all walks of life.

The intersection of syntagmatic and paradigmatic axes may lead to meaning production. Meaning proper is the product of the signification process. These axes of structural semiotic can be plainly shown in the Figure 1.

The narrative text, say the short story, is a unit of meaning, a unit of relation. The cornerstone of the whole process is the sign and the sign system in which meaning is organically produced. The figure may not cover all the formal relations of the sign theory. Still, it gives a general idea of what semiotic theory and its function in meaning production. This

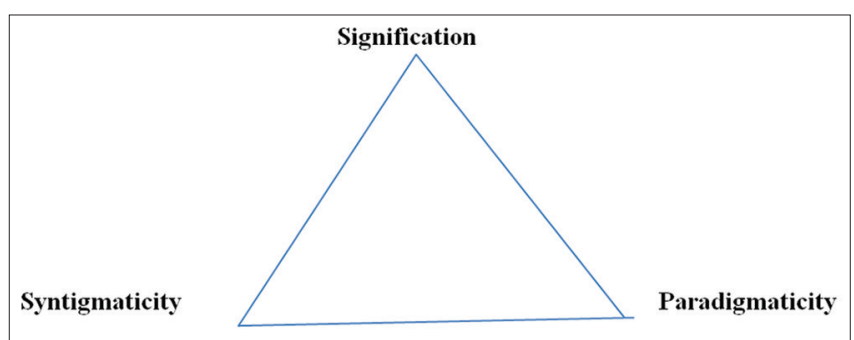

Figure 1. The semiotic triangle in Poe's The Black Cat

theoretical grid may lead us to the analysis of the narrative data, i.e. Poe's The Black Cat.

The motif behind using the semiotic triangle is to cope with the structural parameters of Poe's The Black Cat- those parameters which construe the symbolic meaning and the writer's world view. The semiotic triangle proves its validity to glow the merits of symbols in communicating the writer's spiritual and aesthetic message to the reader. The Black Cat is a par- excellent work of art representing the Gothic Romanticism which prevailed the nineteenth century by and through its grotesque, wild and strange darkish traits. Poe's literary work is not merely bundles of linguistic structure following in a combination.

\section{Poe's The Black Cat: Text Preview}

The Black Cat (1843) is a short story written by Edgar Allan Poe (1809- 1849). Poe was an American writer, editor, and literary critic. Poe is best known for his poetry and short stories, particularly his tales of mystery and the macabre" (Stableford, 2003: 18-19). His fictional works seem to follow the Gothic horror tradition. The Gothic fiction whose first models in the was Horace Walpole's (1764) The Castle of Otranto (later on, A Gothic Story), Mary Shelley's Frankenstein in the second half of the eighteenth century, and Bram Stoker's Dracula in the Victorian literature. The epithet Gothic is derived from the mysterious mansions, architecture and nature scary landscape. So, these haunted places are characterized by gloominess, mystery and death. The whole scene is hued with black and red hues.

Though it was the innovation of the romantic era, the Gothic narrative genre continued to be practiced in the Victorian epoch. The most revealing elements of the Gothic fictional genre is the mediaeval romance with superstitious fanciful paint. Poe's Gothic stories are in the tradition of the Victorian Gothic genre. His most recurring themes deal with questions of death, including its physical signs, the effect of decomposition, concerns of premature burial, the reanimation of the dead, and mounting. Many of his works are generally considered part of the dark romanticism genre (see Wikipedia, 2007). The most revealing elements of the Gothic fictional genre is the mediaeval romance with superstitious fanciful paint. One characteristic designated Poe's creative work is that Poe "focused less on the traditional elements of gothic stories and more on the psychology of his characters as they often descended into madness. Therefore, Poe was viewed as the best interpreter of the Gothic novel. This trait is fundamentally apparent in his The Black Cat. 
Much work has been written on The Black Cat. Critical analyses and summaries endeavor to show the different perspectives of the short story. As narrative technique, the story is told by unnamed unreliable narrator who is obsessed by his intimacy with animals and, then, with his entire insanity. One summery (Shmoop University, 2017) reads as follows.

From his prison, the unnamed narrator is writing the story of how very thing in his life fell apart. Since He will die the next day, he wants to set the record straight, and tells us the story of his life. from the day He was born, he is mild and kind. He loves animals and has lots of them. As he gets older up these qualities grow stronger. Taking care of his pets and hanging out with them is his favorite thing to do. His favorite animal companion is his dog.

Before long, he gets married. His wife loves animals too, and fills the house with a variety of them. One of these is humongous, all black, super-smart cat names Pluto. When the man starts drinking, his personality takes a turn for the worse. He starts physically and verbally abusing his wife and pets. One night, the narrator comes home from partying completely drunk. Thinking Pluto didn't want to hang out with him, he grabs the cat and cuts his eye out with a pen-knife.

One morning, not long after the eye-gouging, the narrator is overcoming with a perverse impulse.

He hangs Pluto from a tree in his garden, murdering him. Writing from his jail cell, the narrator claims he did precisely because he knew it was wrong. That night, the night of the murder, the the man's house catches fire and burns down. Only the man, his wife, and one servant are left alive. But, they lose all their money in the flames, along with the house. When the narrator returns the next day, there is a crowd in his bedroom, looking at his bedroom wall. On the wall is the slightly raised image of a ' gigantic cat' with a rope around its neck.

Since he left the cat hanging all day and night, he figures one of the neighbors cut it down and threw through his window to wake him up. Somehow it stuck in the plaster of the wall. This bothers the man for a long time.

One night when he's drinking, another black cat appears on the scene. This cat looks like Pluto, except for the little white spot on his chest. The man takes the cat home, and his wife is quite pleased.

When it is discovered that this cat is also missing an eye, the man, the man begins to despise it, While the woman loves it all the more. After some time passes, the woman shows the man that The white spot on the cat's fur has grown. Oddly, the white spot now forms an image of " the GALLOWS!" (The gallows is a wooden device used to hang people.).

The man is too afraid of the cat to abuse it. The cat never leaves him alone for a moment, and Even Sits on his chest and breathes in his face when is in bed. So, the man doesn't get any sleep. As his loathing of the cat increases, so does his physical and verbal abuse of his wife. One day he and his wife go down to the cellar of the crummy old house they live in now that they are poor. The cat follows them. In a fit of extreme irritation, the man tries to kill the cat with an axe. The woman stops him, and the man buries the axe in her brain, killing her.

The narrator wonders how best to conceal the body? After much deliberation, the man decides to hide the body in a space behind the cell wall. That night, the man sleeps peacefully for the first time in ages. The cat is nowhere to be seen.

The cope come around, but the man has finesses them. No big deal. On the fourth day, still no cat. But, the police return and search the house again, especially the cellar. Right when they are about to leave, abandoning tier search of the cellar, the narrator decides to start bragging about how well built the house is. He takes his cane and hits the spot in the wall where he's hidden his wife's body.

A noise answers his knock! It is a sad sound, like a kid crying. It sounds horrible and desperate, But also victorious. The police are on it. They take down the wall only to find the dead body, with the cat on top of its head. And that's why the narrator is in jail, sentenced to death by hanging. The narrator had accidently shut the cat up in the wall with the body.

A wittingly captious summery as such may provide us with basic elements of the short story, in general and Poe's narrative text, in specific. Of these elements are narrative point of view, narrative voice and narrative time.

As for the narrative point of view, the story is communicated to the reader from an unknown narrator who proclaims to be insane. Being structured on the first-person point of view, The Black Cat is revealed through a narrator who is also explicitly a character within his or her own story. Therefore, the narrator reveals the plot by referring to this viewpoint character with forms of "I" (i.e. the narrator is a person who openly acknowledges his or her own existence.) (see Narration, 2017). The narrator is the protagonist himself who committed that serial of murders which eventually led to be sentenced into death. The narrator, in Poe's short story, is the participant or the doer whose guilt has led him to execution the next day. He is the focal character who transmits through his written confession the facts about his murderous actions to the reader.

Narration, however, construes not only who is the doer of the actants or the actor, but also the style or how these actants are narrated. In Poe's The Black Cat, there is a sense of unreliable narration. The actor doesn't expect the reader to believe him: "For the most wild yet most homely narrative which I am about to pen, I neither expect nor solicit belief." (Adelaide, 2004). One more point about the main character is that in spite of the horrible deeds he has committed, he denies to be looked at as a mad man: "Mad indeed would I be to expect it, in a case where my very senses reject their own evidence. Yet, mad am I not- and very surely do I not dream" (bid). What is characteristic about the narrator is that he is a sort of round character. His career starts as a mild descent person who whose is obsessed by pets, and ends as a murderer whose purpose is " to place before the world, 
plainly, succinctly, and without comment, a series of mere household events"(ibid). The main cause behind that psyche transformation is alcoholism. One may notice a sort of narrative parallelism between the cat and alcohol in diverting the course of events in the story.

No plot can take place without a setting (i.e. the location, the time and the socio-cultural circumstances). The storylines happen in two main locations: the narrator's house where he, his wife and pets live, since, in the narrator's words, "I was especially fond of animals" and " this peculiarity of character grew with my growth, and, in my manhood, I derived from it mone of my principal sources of pleasure." (ibid). The other location is the old house with a cell where the whole family live in poverty. The exceptional location is the jail cell where the narrator writes his story in the even before the day of execution. Being a story narrated from the first-person point of view, the events are told in the past tense. So, the past verbal groups are the salient stylistic feature of the narration. The point to be stressed here is that the story, as one whole unit, described as homely narrative though it is the wildest narrative. But still, the Gothic traits of gloom, mystery, death, superstition and the macabre vision are most picturesque features of The Black Cat.

\section{The Semiotic Interpretation of the Black Cat}

Narrative, as already denoted, is a set of sequential story-telling signs and symbols. The most revealing sign we encounter in Poe's narrative text is the black cat with its doubled image (i.e. the black cat with white spot on the skin) in the due course of narration. The first clue about the symbolicity of the animal has come from the narrator's wife "at heart was not a little tinctured with superstition, made frequent allusion to the ancient popular notion, which regarded all black cats as witches in disguise" (ibid). But before delving deeper in such symbolicity, let us analyze the episode(s) as a sequence of semiotic structures.

In its syntagmatic-paradigmatic construction, there is a frequent recurrence of the sign the black cat, as in

We had birds, gold-fish, a fine dog, rabbits, a small monkey, and a cat. This latter was a remarkably large and beautiful animal, entirely black, and sagacious to a astonishing degree. In speaking of his intelligence. (ibd:4).

Pluto - this was the cat's name- was my favorite pet and playmate. I alone fed him, and he attended me wherever I went about the house (ibid).

Even Pluto began to experience the effects of my ill temper(ibid:5)

I fancied that the cat avoided my presence. I seized him; when, in his fright at my violence, he inflicted a slight wound upon my hand with his teeth. The fury of a demon instantly possessed me. I took from my waistcoat- pocket a penknife, opened it, grasped the poor beast by the throat, and deliberately cut one of its eyes from the socket!(ibid)

I experienced a sentiment half of horror, half of remorse, for the crime of which I had been guilty; but it was, at best a feeble and equivocal feeling, and the soul remained untouched (ibid: 5)
I slipped a noose about its neck and hung it to the limb of a tree; - hung it with the tears streaming from my eyes, and with the bitterest remorse at my heart; - hung it.

I could not rid myself of the phantasm of the cat; and, during this period, there came back into my spirit a half-sentiment that seems, but was not, remorse(ibid:6)

It is suffice to note that the sequential events are narrated in a linear combinatory structures from the first- person point of view. The linearity of the story, here and elsewhere, follows the movement of the mind where the nominal group as the actor is followed by the verbal group, then by the patient or the thing that is affected by the horrible act(s). The doer is not necessary to be the human or the narrator himself.

Interweaved with the syntagmatic relation is the paradigmatic relation. Here comes the axe of substitution. The sign cat has got several substitutions. Syntactically, on the lever of common noun, we witness the use of Pluto, pet, animal and beast. On the level of pronoun, detect he, him, it, and its. These deictic items have reoccurred more than once in the texture of the narrative text. The syntagmatic- paradigmatic relations operate forcefully to produce the forms of meaning in the larger text, i.e. The Black Cat. In this mutual relation, the signification process does exist: The black cat as sign powerfully represents, not only the mammal beast in the physical world, but also the concept of death which organically rooted in the veins of the story. There is a relation that holds between the form (cat) and its referent (animal). When the sign is associated with other senses in a given cultural code, it becomes a symbol. Here, the cat becomes a symbol of death. In addition, it is associated with darkness, which becomes the alternative sign of death. In other words, the meaning of darkness and death is generated by the use of semiosis. These interrelated axes or structural relations are the landmark of the narrative text. This complex network of interrelated signs is organically rooted in culture; it is the intrigued cultural representation.

What matters to this study is the symbolicity of the sign, more specifically, the sign Pluto. In his preference to the pet, the narrator confesses: "Pluto- this was the cat's name- was my favorite pet and playmate." (ibid). It is strange, albeit, to detect that semantic contrast between the narrator's love and intimacy towards the pet and its symbolic meaning as a sign. In his preference to the pet, the narrator describes it as a supernatural animal- "a remarkably large and beautiful animal, entirely black, and sagacious to an astonishing degree," in addition to its intelligence, but what about the cat as a generic species in mythology? In A Dictionary of Symbols (1971:39), Cirlot believes that "the Egyptians associated the cat with the moon, and it was sacred to the goddesses Isis and Bast, the latter being the guardian of marriage. A secondary symbolism is derived from its colour, the black cat is associated with darkness and death. This linkage of the cat to death may explain its association with Pluto. In Greek and Roman mythology, Hades, god of the dead and the underworld; also called Ades; Aides, Aidoneous, Pluton (Mercatante and Dow, 2009:788). So, death is one of the salient signs, not only in this narrative text, but also in the Gothic romantic narratives as well. A symbol, in the literature of semiotics, is 
a sign that stands for an idea, an image, visual or verbal, or even a belief. In our semiotic analysis, Pluto (a signifier) is tied up to the idea of death(signified), which a crucial part of the horror code. So, horror, which pervails the walks of the story texture, becomes in behavior and cognitive patter(s) a cultural mode. The signs of this cultural mode (i.e. crime, remorse, ungovernable outbursts of fury, suffering, wretchedness, angry, corpse, grave, unutterable fear, agony, death) exist in the narrative semiotic network system.

Relevant to the main symbol in the story is the image of the black cat, similar to Pluto, but with a white spot. Still, the inquiry concerns the motif behind inventing such doubled image with this seemingly slight physical appearance. In his brilliant literary criticism in the early 1970 s, Todorov has introduced the term fantastic to discuss the literature of horror and to find out the boundaries between the natural and the supernatural in works of art. The fantastic is a literary category that contains elements of both elements the rational and the irrational (SparkNotes, 2017). Applying Todrrov's fantastic to Poe's The Black Cat shows that the doubled cat is but the creation of the psychopathic cognition of the narrator- with the changing shape of its white fur and its appearance on the corpse behind the wall. These plot twists challenge reality, but they do not completely substitute a supernatural explanation for a logical one. It is possible that the plot twists derive only from the insanity of the narrator. As a result, the plot twists, like the fantastic hover between the real and the supernatural. The resolution of the story is both rationally possible and tremendously unlikely; the cat could inhabit the basement walls, but it is difficult to believe that it would remain silently in the wall for a long time or go unnoticed by the overly meticulous narrator (ibid). From a paradigmatic stance, the second cat is designated with nouns and pronouns, so,

She followed (Poe, 2004: 7-9)

The cat followed me (ibid)

aimed a blow at the animal (ibid)

Such substation is not aimed to be merely a stylistic variation. Rather it shows the variant degree of the psychological transformation of the narrator's psyche from intimacy to disgust.

One point to be point to here, is that the transformation of the white spot on the cat's fur has led to the appearance of the Gallows- another sign needs to be more explored. The event is narrated as follows:" It was now the representation of an object that I shudder to name- and for this above, I loathed, and dreaded, and would have rid myself of the monster- it was now, I say, I say, the image of a hideous- of a ghastly thing- of the GALLOWS!- oh, mournful and terrible engine of Horror and of Crime- of Agony and of Death!((ibid:8).

Let us first consider the stylistics of the narrator's confession and how the extreme psychological infatuations and hallucinations lead to the deformation and estrangement of the narrator's language. The whole uttered confession is characterized by staccato diction, broken phrases and. The sign Gallows is mentioned at the height of the narrator's feeling of guilt. Narrator's discourse provides an instance of transition in style. The onset of the discourse flows easily with complete structures that enrich the reader with sufficient knowledge to analyze the narrator's cognitive state of mind, and ends with the stylized images of irritation where the signs of horror, crime, agony and death are the most salient in the discourse. We can infer from the tempo of the discourse and the diction used the state of horror the actor lives by. The flow of the combinatory signs in the structures witness certain pitfalls because of the intense of the cognitive and psychological pressures the actor encounters at the high peak of his confession. So, it is not altogether wrong to talk about the code of horror in the story. The horror code is organically related to the psychopathic moment the narrator undergoes after the serial of crimes he has committed. Denotatively speaking, the gallows is the structure or the device where the criminal who is sentenced to death is to be executed. Paradigmatically, the gallows becomes "an object that I shudder to name," then it becomes "a ghastly thing". As a representation, the sign stands for the idea of punishment in legal and divine terms, but since this ghastly thing is an image, hence, the murderous narrator undergoes that psychological torment before the day of his physical death.

In addition to the signs of horror, crime, agony, dread and death which build up the mental universe of The Black Cat, we may refer to the sign evil, which is mentioned more than one in the fabric of the narrative,

This dread was not exactly a dread of physical evil- and yet I should be at a loss how otherwise to define it.

Evil thoughts became my sole intimates- the darkest and most evil of thoughts.

This sense of evil is accompanied with the sense of hatred: "The moodiness of my usual temper increased to hatred of all things and of all mankind "(ibid). The sufferer of these hideous murders is not the beast only, but also the human, i.e. his wife who describes her as "the most patient of suffers, and whose life is ended by the axe buried in her brain. If we add more signs related to horror code like corpse, grave, violence, cellar, monster, we can make up the culture of horror out of these sequential signs.

Our semiotic analysis mainly deals with the way meaning is structured and produced by a sequence of interconnected signs and symbols, by the specific so-called, the code of horror. That code is a part of a given culture, i.e. the culture of horror, if we consider the term culture as a complex networking of beliefs, behaviors and patterns of cognition. All the ways of the ways of thinking and actual behaviors prove his inhuman abnormality or insane mind though he, in his written manuscript, demies that. Though he believes that he was "indeed wretched behind the wretchedness of mere Humanity," (ibid: 8), he actually psychopathically of how to get rid of his wife's corpse after killing her with an axe in a storm of rage: "At one period I thought of cutting the corpse into minute fragments, and destroying them by fire. At another, I resolved to dig a grave for it in the floor of the cellar. Again, I deliberated about casting it in the well of thee yard- about packing it in a box."(ibid). Then, his sick mind has invented a witty way to conceal the corpse: "I determined to wall it up in the cellar, as the monks of the Middle Ages 
are recorded to have walled up their victims." The narrator, as his confessions show, is not merely a murder, but a witty reader who exploits his human knowledge for evil schemes. These sequential murderous events with all their interrelated symbols turn the larger text (the narrative in question) into a sort of analogy with reality, into a sort of metaphor. This point requires more insight. Signification, as denoted, is the relation between the signifier and the referent." Being a meaning transfer, a trope in the semiotic sphere witnesses an aesthetic violation of meaning transfer, but the analogy between the literary text and reality does exist. The forms of the world are molded in systems of verbal signs. The ubiquity of tropes in visual as well as verbal forms, in Chandler's words (2002: 125), “" can be seen as reflection our fundamentally relational understanding of reality. Figures of speech enable us to see one thing in terms of another." Chandler (ibid) concedes to say that a trope such as metaphor can be regarded as a new sign from the signifier of one sign and the signified of another. The signifier thus stands for a different signified; the new signified replaces the usual one. The signifier Pluto of associative nature; it stands for the abstract idea of death which is the dominant symbol of the text. The gallows represents that psychological punishment for a physical crime, which causes the murderer an eternal torment. Hence, it is possible to refer to the semiotics of metaphor in the interdisciplinary field of social semiotics since our semiotic interpretation is seminally concerns with homely events. The complex network of the interlinked symbols represents the sickness of mind sphere, which is a crucial part of reality. Not all mental diseases, off course, are of genetic nature. In the case study like the narrator, the mild descent character turns into an addict murderer because of an outer impulse- his alcohol addiction. This obsession of humans and pets turns into obsolete brutality. In the cinema sphere, analogous to the literary creative sphere, the structure of a film like The Silence of Lambs (1991) is similar to that of Poe's The Black Cat. Due to the narrative course of the movie, Dr. Hannibal Lecter is a brilliant psychiatrist, but still he is a cannibalistic serial killer. Movies and narratives, being forma of meaning and products of cultures, stand as representations of realties, but, this time, sick mental realities.

\section{CONCLUSION}

The semiotic interpretation here above may lead us to conclude that that Poe's The Black Cat is the representation of the psychopathic complexity of human nature via semiosis. The signs of horror, atrocity, guilt, evil, and darkness, which are encoded in the code of horror, operate reciprocally to construct the convention of horror; it is the culture of horror that domains the veins of the narrative text. One result of the study has shown that fear is not an organic human nature in The Black Cat, but a newly born behavior which has led to a serial of crimes committed by the unnamed author. Therefore, the semiotics of culture is not without relevance to the psychopathic impulses the narrator feels in and after committing the deadly deeds.
The other result is that the movement of the structure of The Black Cat, and necessarily, the nature and function of signs may correspond with the movement of the narrator's mentality. From a narrative stance, the narrator is a round character whose horrible deeds are the natural consequences of his changeable mental states. The study has recourse to the Semiotic Triangle (ST) with its structural relations to detect the meaning produced by the intersection of these axes. The validity of the model is to expose the forms of meaning structured in the combinatory sequences of signs and symbols which create the texture of the narrative text. In addition, Poe's The Black Cat with all semiotic images and symbols communicates a human message. The Black Cat, being a larger narrative text, does not communicate merely a moral message against alcohol addiction. Rather, it is the exposition of an abnormal human category, i.e. an imaginatively sick life style, which is actually practiced in reality.

\section{REFERENCES}

Barthes, R. (1975). On Narrative and Narratives. New Literary History, $6(2)$.

Cirlot, J.E. (1971). A Dictionary of Symbols. London: Routledge

Chatman, S. (1978). Story and Discourse: Narrative Structure in Fiction and Film. Ithaca and London: Cornell University Press.

Chandler, D. (2007). Semiotics: The Basics. New York: Routledge.

Crystal, D. (1997). A Dictionary of Linguistics \& Phonetics ( $5^{\text {th }}$ ed.) USA: Blackwell Publishing.

Danesi, M. (2007). The Quest for Meaning. Toronto: University of Toronto Press.

Danesi, M. (2004). "Messages, Signs, and Meanings: A Basic Textbook in Semiotics and Communication." In Studies in Linguistics a \& Cultural Anthropology ( ${ }^{\text {rd }}$ ed.). Vol. 1.Toronto: Canadian Scholars', Inc. Press

Danesi, M., and Sebeok, T. (2000) The Forms of Meaning: Modeling Systems Theory and Semiotic Analysis. Berlin: Walter de Gruyter Gmb H \& Co.

Fogarty, S. (2005) The Literary Encyclopedia.]on Line [, Available from: File:///I:/Binary\%20oppostiton520-\%20 Wikipedia, $\% 20^{\text {th }} \mathrm{e} \% 20 \% 20$ free $\%$ encyclopdeia.ht. [Accessed 11August, 2017[]

Mercatante, A., and Dow, J.R. (2009) World Mythology and Legend, $3^{\text {rd }}$ ed., New York: Fact on File, Inc.

Narration (2017)) [on Line, [Available from: https://en.Wikipedia.org/wiki. Narration] Accessed 8 August, 2017]

Poe, E.A. (2004) The Black Cat. Adelaide: University of Adelaide.

Poe, E.A. (2017).[on Lin], Available from: https://en. Wikipedia.org/wiki. Edgar Allen_Poe [Accessed 2 August, 2017]

Phillips, J.W. (2016) Structure and Semiotics [on Line], Available from:

https://course. Nus.edu.sg/couse/elljwp/structural linguistics.htm[ Accessed4 August, 2017]

Sebeok, T. A. (2001). Signs: An Introduction to Semiotics 
( $2^{\text {nd }}$ ed.) Toronto: Toronto University Press.

Spark, N. (2017) Poe's Short Stories: “The Black Cat (1843)] [on Line], Available from: http://www.sparknotes.com/lit/poesstories/section8/ page/2/[Accessed 16August, 2017].

Stanford Encyclopedia of Philosophy. (2010). Peirce's Theory of Signs.[on Line] , Available from: https://plato.stanford. edu/entries/peirce-semiotics [Accessed 16August, 2017]

Trask, R.L. (1993). A Dictionary of Grammatical Terms in
Linguistics. London and New G.K. Hall \& Co.

Stableford, B. (2003). "science Fiction before the genre". In James Edward; Mendelsohn, Farah. The Cambridge Companion to Science fiction. Cambridge: Cambridge University Press.

The Black Cat Summery. (2017). Shmoop University [on Line]. Available from: http://www.shmoop.com [Accessed 7 August, 2017] 